\title{
CORRESPONDENCE
}

\author{
FLETCHERINA, A NEW NAME FOR A PALAEOZOIC \\ CORAL GENUS
}

SiR,-Dr. Dorothy Hill has drawn our attention to the fact that the coral generic name Yabeia Lang, Smith and Thomas [Index of Palaeozoic Coral Genera, Brit. Mus. (Nat. Hist.), 1940, p. 140], proposed for Cylindrophyllum Yabe and Hayasaka (Journ. Geol. Soc. Tokyo, xxii, 1915, p. 90) non Cylindrophyllum Simpson [Bull. N.Y. St. Mus., viii (39), 1900, p. 217], is itself a junior homonym of Yabeia Resser and Endo in Kobayashi [Journ. Fac. Sci. Tokyo (Geol. 2), iv (2), 1935, p. 90 (footnote)], a name introduced for a trilobite. We, therefore, propose the name Fletcherina to replace Yabeia Lang, Smith and Thomas and $C y$ lindrophyllum Yabe and Hayasaka ; the type species is, of course, C. simplex Yabe and Hayasaka.

We have chosen the name Fletcherina because we consider the genus is at least closely allied to Fletcheria Edwards and Haime (Arch. Mus. Hist. Nat., v, 1851, pp. 156, 300). The main differences between the genera appear to lie in the calicular increase and numerous septal striae of the latter, compared with the stated lateral increase and absence of septa and septal spines in Fletcherina.

Wang (Phil. Trans. Roy. Soc. Lond., B, cexxxiv, 1950, p. 206) places Pycnostylus Whiteaves, Placophyllum Simpson, Cylindrophyllum Yabe and Hayasaka (non Simpson) and Synamplexus Grabau in the synonymy of Fletcheria. We reject Placophyllum from this synonymy as that genus is a Spongophyllid (cf. Stumm, Mem. Geol. Soc. Amer., xl, 1949, pp. 28, 30). The others are all ampleximorphs; as with all such genera, their synonymies and relationships are matters of some doubt and difficulty, and must remain so until their type species can be critically re-examined and compared.

Although Edwards and Haime (op. cit.), followed by Nicholson (On the Structure and Affinities of the "Tabulate Corals" of the Palaeozoic Period, 1879 , pp. 203, 206), referred Fletcheria to the Tabulate corals, Wang (op. cit.) placed it in the Rugosa. Not only do we believe him to be right in so doing, but we also place Fletcherina in the Rugosa.

W. D. LANG.

STANLEY SMITH.

Department of Geology,

H. DightoN ThOMAS.

British MUSEUm (NaTURAL History),

CromWEll RoAD,

LONDON, S.W. 7.

\section{THE UBENDIAN IN WESTERN TANGANYIKA}

SIR,-The recently published study of the metamorphic rocks of Karema and Kungwe Bay, Western Tanganyika, by J. Sutton, J. Watson, and T. C. James (1954), is a type of work which is unfortunately all too rare in East Africa ; it represents the results of the detailed mapping of two small areas of the Basement Complex followed by exhaustive and up-to-date laboratory investigation. The areas studied lie in the Ufipa and Ubende regions of which I made a reconnaissance study during the years 1943 and 1944, and published a provisional geological map on a scale of $1: 300,000$ (1950). I do not wish to discuss at present the extremely interesting conclusions regarding the metamorphic complexes arrived at by Drs. Sutton and Watson, but I feel that I must ask them to reconsider the alterations which they propose in my classification of the Basement rocks of Ubende and Ufipa. This country is very difficult of access as, in some 6,000 square miles, there were, at the time of my work, only two motor roads : the geologist has therefore to rely on transport by porters, and since the population has 